\title{
The Mechanical Destruction of Bacteria
}

\author{
By H. K. KING AND HAZEL ALEXANDER \\ The Bacteriology Department, University of Edinburgh
}

\begin{abstract}
SUMMARY : A number of different organisms were subjected to violent shaking with minute round glass particles. Vegetative bacteria, spores, and acid-fast species were killed by this treatment, though at varying rates.

Curran \& Evans (1942) described the destruction of bacterial spores by violent agitation with small inert particles. Several workers (e.g. Gale, 1947) have applied this technique to the extraction of enzymes from vegetative cells. Unlike other mechanical methods (e.g. sonic disintegration or the use of bacterial mills) it requires no elaborate equipment, and the risk of damage to proteins or other labile cell constituents is less than with methods involving autolysis or the use of chemical agents. Curran \& Evans (1942) obtained large decreases in the viable count of spore suspensions by this method and claimed (though without giving experimental data) that suspensions of Bacterium coli may be completely sterilized. We have investigated a wider range of both sporing and non-sporing bacteria. In confirmation of Curran \& Evans's findings we obtained a rapid exponential fall in the number of viable organisms: but a small proportion of the cells appeared to be much more resistant to this treatment than the others present in the same bacterial suspension.
\end{abstract}

\section{METHODS}

Bacterial suspensions. The organisms tested were mainly from our laboratory stock. They were grown for $24 \mathrm{hr}$. (48 hr. for Mycobacterium smegmatis) at $37^{\circ}$ on the surface of nutrient agar, with addition of $0.1 \%$ glucose and $10 \%$ horse blood for the pneumococcus, washed off with physiological saline, washed twice with saline, and resuspended in the fluid (usually saline) in which they were to be shaken. The cultures of Bacillus subtilis, B. mesentericus and B. anthracis were allowed to stand at room temperature for $a$ few days before preparing the suspensions, which consequently consisted mainly if not entirely of spores. Suspensions of yeast were prepared from commercial brewers' yeast by repeated washing with saline.

All suspensions were adjusted to an opacity equal to Brown's tube no. 3, which corresponds to about $10^{9}$ organisms $/ \mathrm{ml}$. in most cases. Exact adjustment of the initial count was not practicable since, for reasons stated later, the 'initial' was taken after a short period of shaking during which a variable degree of killing took place. All precautions to avoid extraneous contamination were taken throughout.

Particles. Curran \& Evans (1942) employed several types of particles and found small smooth glass beads to be the most suitable. We obtained these from Messrs Chance Bros. Ltd., Smethwick, England, under the trade name 'ballotini'. Three grades were supplied whose mean diameters, measured 
under the microscope, were: grade $6,0.80 \mathrm{~mm}$., grade $9,0.26 \mathrm{~mm}$. grade 12 , $0.13 \mathrm{~mm}$. Grade 9 was used unless otherwise stated; grade 12 may be more efficient, but supplies were limited at the time.

Shaking machine. An ordinary laboratory shaker was used, accommodating two $4 \mathrm{oz}$. medicine type flat bottles laid lengthwise on their narrow sides. Speed was 300-350 strokes/min. with an amplitude of $2 \frac{1}{2}$ in. There was no means of ensuring that speed remained constant, and the electric main supply was subject to serious fluctuations. The agreement between replicates indicated, however, that variations in the speed of the shaker did not materially affect our results.

Procedure. The beads were washed with chromic-sulphuric mixture, rinsed thoroughly with water followed by acetone, dried and sterilized in the hot-air oven before each experiment. $40 \mathrm{ml}$. of bacterial suspension, prepared as described above, were placed in one sterile $4 \mathrm{oz}$. bottle with $50 \mathrm{~g}$. of beads. The bottle was closed with a rubbler-lined screw cap and placed in the shaker. After 15-20 min. shaking a $1 \mathrm{ml}$. sample was aseptically withdrawn and a viable count made. This was taken as the 'initial' count. A count taken before shaking was begun was liable to give misleading results as the organisms, in some cases, adhered together in clumps. Further counts were made at intervals of 1-2 hr. up to $10 \mathrm{hr}$, and a final count, in some experiments, after $24 \mathrm{hr}$. shaking. The experiments were performed at room temperature, usually about $10^{\circ}$. The prolonged shaking did not produce any appreciable rise in temperature but when speed was increased to 600 strokes/min. a rise of a few degrees was observed.

Viable counts. $1 \mathrm{ml}$. of the suspension was withdrawn and serial tenfold dilutions in saline prepared. $1 \mathrm{ml}$. of each of four suitable dilutions were placed in Petri dishes and $15 \mathrm{ml}$. melted nutrient agar added; for the enterococcus and the pneumococcus this medium was enriched with $10 \%$ of serum. Colonies were counted after incubation at $37^{\circ}$ for $48 \mathrm{hr}$. (4 days for Myco. smegmatis) and the number of viable organisms/ml. estimated. When spore counts were required, the vegetative forms were killed by heating for $15 \mathrm{~min}$. at $70^{\circ}$. With yeast, the counts were made by stroking one loopful $(0.001 \mathrm{ml}$.) on the surface of a Petri dish containing Sabouraud's medium and incubating at $20^{\circ}$ for 3 days.

\section{RESULTS}

Method of expressing results. Since the killing of micro-organisms by this method (in common with most sterilization processes) followed an exponential law, results were expressed by plotting the logarithm of the fraction of surviving organisms against time. The fraction of organisms surviving was plotted rather than the viable count itself, since the unavoidable variations in the initial count made comparison of graphs of viable counts more difficult. The actual initial count is stated on each graph.

The logarithmic plot assumed a slope which provided an index of the rate at which killing took place. This was expressed in terms of the 'decimal reduction time' (D.R.T.), i.e., the time required to effect a tenfold reduction in 
the viable count. The process did not however proceed to completion at a uniform rate: when a certain proportion of the cells had been killed the slope of the curve was diminished (e.g. Fig. 1, curve $C$ ) indicating that a small fraction of the cells were resistant to this treatment or at least exhibited a much longer D.R.T. than the remainder. This phenomenon, discussed below, necessitated expression of the results in terms of both the D.R.T. and the proportion of 'resistant' organisms. It was difficult to determine more than the order of magnitude of the latter, since exact evaluation was prevented by the preliminary period of shaking required before the 'initial' count. During this period destruction of the normal cells will proceed more rapidly than that of the 'resistant' organisms.

\section{Course of the process}

Fig. 1, C, illustrates a typical experiment with Bacterium coli. Up to $10 \mathrm{hr}$. killing proceeded in accordance with the exponential law, the D.R.T. being $2 \cdot 1 \mathrm{hr}$., with the viable count decreased to $c \cdot 1^{-5}$ of its original value. Sterilization ceased at this stage, and little further fall in the viable count took place. These figures were confirmed in several replicate experiments performed on different occasions. The same D.R.T. and the same proportion of survivors were obtained with suspensions of only $1 / 10$ the original density. No appreciable fall in the viable count was observed when the suspension was left in contact with the beads but not shaken (Fig. 1, curve $A$ ), and only a slight fall when shaking was carried out in the absence of the beads (Fig. 1, curve $B$ ).

The apparently high resistance of a small number of cells towards a process lethal to the majority was an unexpected finding. It was necesary to establish that this phenomenon was not due to some factor related to our technique (such as the protection of a small number of cells beneath the rubber lining of the stopper which closed the vessel in which shaking took place), though the constancy of the proportion of survivors for a given species made this explanation seem improbable. The phenomenon was investigated by shaking a suspension of Staphylococcus aureus for $12 \mathrm{hr}$; this decreased the viable count from $10^{\circ} / \mathrm{ml}$. to a constant value of $1500 / \mathrm{ml}$. The suspension was then transferred aseptically to another bottle containing fresh sterile beads and shaking continued for a further $9 \mathrm{hr}$. No significant fall in the viable count took place. At the same time a fresh (unshaken) suspension containing 2000 cells $/ \mathrm{ml}$. was shaken with beads in the usual way. In this control suspension the normal killing action was observed, except that the D.R.T. was considerably longer than that obtained with the much denser suspensions of Staph. aureus normally used (Table 1). The possibility that the 'resistant' cells owed their survival to protection by cell debris was also considered, though this seemed unlikely as the proportion of resistant cells was within wide limits independent of the initial density, and protection by debris would become apparent as soon as a substantial proportion of the cells had been disintegrated. The D.R.T., however, was found to remain constant until all but a minute fraction were destroyed. Moreover, when a suspension of Staph. aureus was shaken for $18 \mathrm{hr}$. (i.e. until the viable count became constant) and then reinoculated with a few drops of a dense 
suspension of fresh cells, the latter were killed at the normal rate when shaking was continued. It also seemed unlikely that cell multiplication could play any

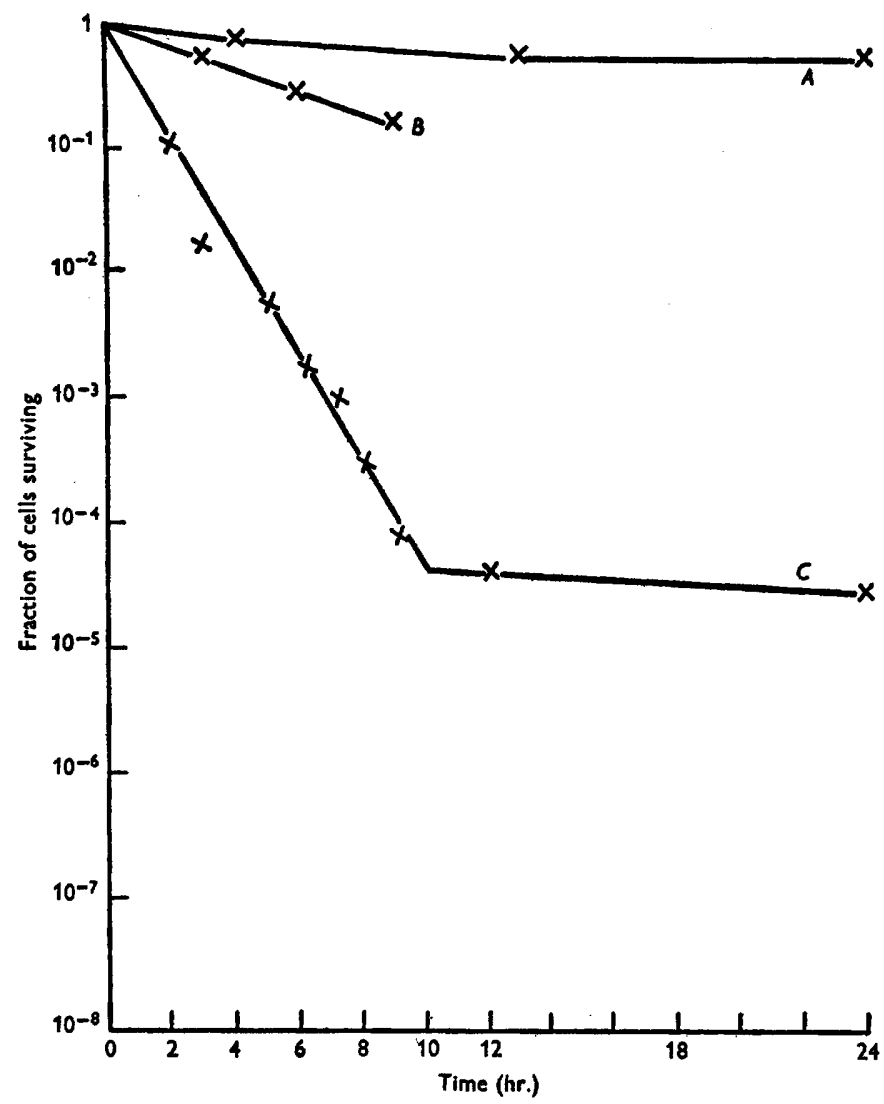

Fig. 1. Effect of shaking with and without beads. Bact. coli. A, control, standing with beads but not shaken; $B$, shaken without beads; $C$, shaken with beads. Initial count $10^{8.5}$ viable units $/ \mathrm{ml}$. in each case.

Table 1. Relative resistance to mechanical destruction of normal and 'resistant' cells

$\begin{array}{ccc}\text { Tiable counts (organisms/ml.) } & \begin{array}{c}\text { Staph. aureus } \\ \text { previously shaken }\end{array} & \begin{array}{c}\text { Untreated } \\ \text { control } \\ \text { for } 12 \mathrm{hr} .\end{array} \\ \begin{array}{c}\text { cells } \\ \text { Time (hr.) }\end{array} & 1500 & 2000 \\ 3 & 1100 & 500 \\ 6 & 1300 & 190 \\ 9 & 1200 & 150\end{array}$

part. The generation time of a typical organism (e.g. Bact. coli) at the temperature of our experiments, even in an optimal medium, would be at least $2 \mathrm{hr}$., corresponding to a decimal increase time of $7 \mathrm{hr}$. When shaking was performed 
in broth, however, the 'resistant' cells did multiply more rapidly than they were destroyed; and once the normal, susceptible, cells were killed, the viable count increased slightly during the period 10-24 hr. (Fig. 2, curve $A$ ).

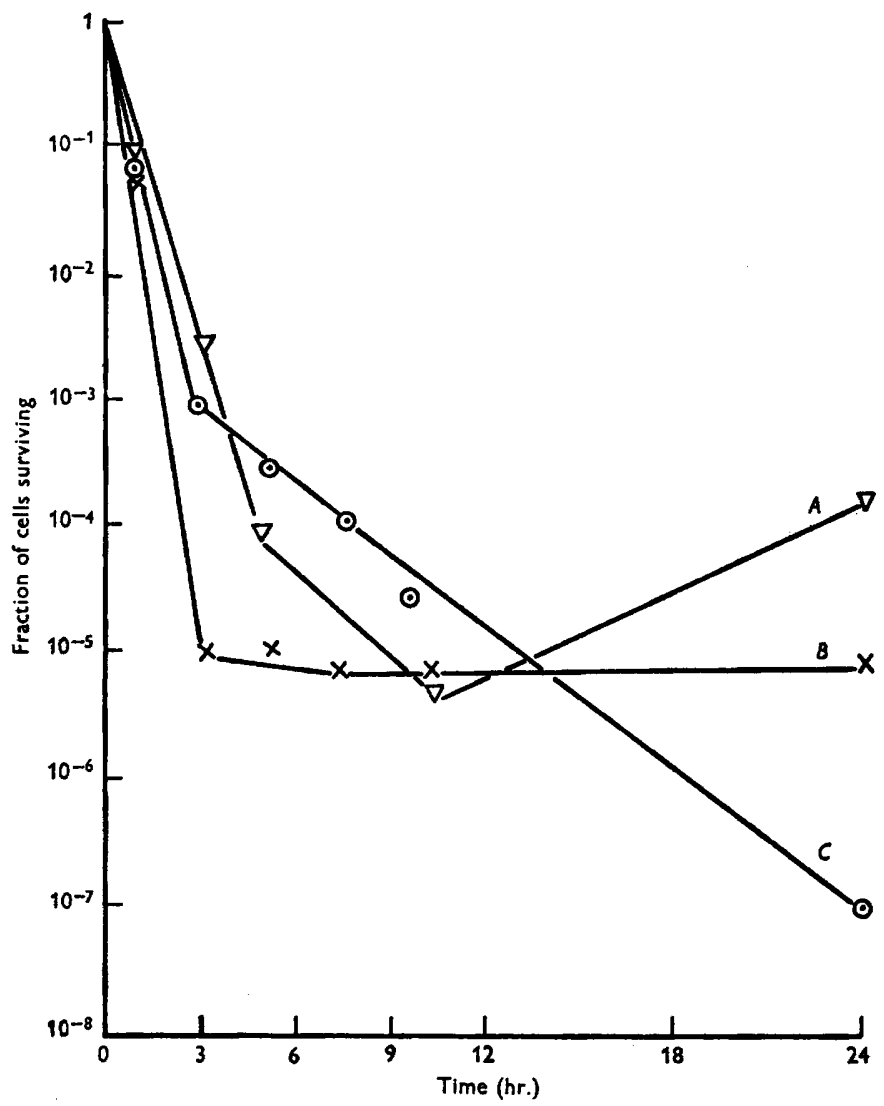

Fig. 2. Destruction of Staph. aureus in various suspending fluids. $A$, broth, initial count $10^{8.6} / \mathrm{ml}$; $B$, water, initial count $10^{7.4} / \mathrm{ml}$; $C$, saline, initial count $10^{7} / \mathrm{ml}$.

Resistance did not appear to be a genetic property. A suspension of Staph. aureus was shaken for $15 \mathrm{hr}$. and then subcultured on nutrient agar. As soon as growth was sufficient the organisms were harvested and again shaken for $15 \mathrm{hr}$. This was repeated twice without producing any change in either the D.R.T. or the proportion of resistant cells.

\section{Factors affecting the killing of organisms}

Size of beads. We found the two smaller sizes (diam. 0.26 and $0.18 \mathrm{~mm}$. respectively) to be about equally effective (D.R.T. with Staph. aureus $1.4 \mathrm{hr}$.) and considerably more effective than the large size (diam. $0.86 \mathrm{~mm}$.) which gave a D.R.T. of $2 \cdot 8 \mathrm{hr}$. under the same conditions. The size of even the smallest beads is still large compared with that of the bacteria. 
Optimal proportion of beads to suspension. This was found to be approximately equal weights of each.

Suspending fluids. Three were investigated, viz. water, saline and nutrient broth (Fig , 2). Water and saline gave approximately the same D.R.T. but the resistant organisms were slowly destroyed in saline whilst able to survive indefinitely in water. In broth considerable frothing took place. The D.R.T. was

Table 2. Decimal reduction time (D.R.T.) and proportion of resistant cells in various organisms shaken with minute glass beads

\begin{tabular}{lcc}
\multicolumn{1}{c}{ Organism } & D.R.T. (hr.) & Proportion of resistant \\
cells
\end{tabular}

increased and the resistant cells, in this nutrient medium, were able to multiply faster than they were destroyed. Fig. 2 is based on experiments performed some time after the bulk of this work : a shaker operating at 450-500 strokes/min. was in use, and a decreased D.R.T. was obtained.

\section{Investigation of various organisms}

The relative susceptibility of various organisms is illustrated by Table 2 and Fig. 4. With Staph. aureus (Oxford ' $H$ ' strain) four replicate experiments gave D.R.T. of $1.4,1.4,1.35,1.45 \mathrm{hr}$. respectively (two of these experiments are illustrated by Fig. 3, curves $A$ and $B$ ). Curve $C$, Fig. 3, represents an experiment with the shaker operated at 450-500 strokes $/ \mathrm{min}$. The proportion of resistant cells was found to be the same, but the D.R.T. was reduced to $0.45 \mathrm{hr}$. and the 'resistant' cells themselves were slowly destroyed. Gram staining of Staph. aureus after several hours' shaking showed a few Gram-positive cells, the debris being Gram-negative. Staining by the Indian ink capsule method revealed the presence of 'ghosts'. Myco. smegmatis, with a D.R.T. of $3.2 \mathrm{hr}$., was the most resistant bacterium studied; the $18 \mathrm{hr}$. period of shaking was not sufficient in this case to determine whether any cells were resistant. The disintegrated organisms were not acid-fast. After $18 \mathrm{hr}$. no intact bacilli could be seen in a stained film, though the viable count was still 10,000/ml.

Yeast proved comparatively resistant to this treatment (D.R.T. approx. $9 \mathrm{hr}$.). The lower initial count in this experiment (Fig. 4, curve $A$ ) was due to the standardization of the suspension to the same opacity as the bacterial 
suspensions used. It may be emphasized that the technique used was that found to be most effective for the destruction of bacteria; possibly a more rapid destruction of yeast might be obtained under different conditions.

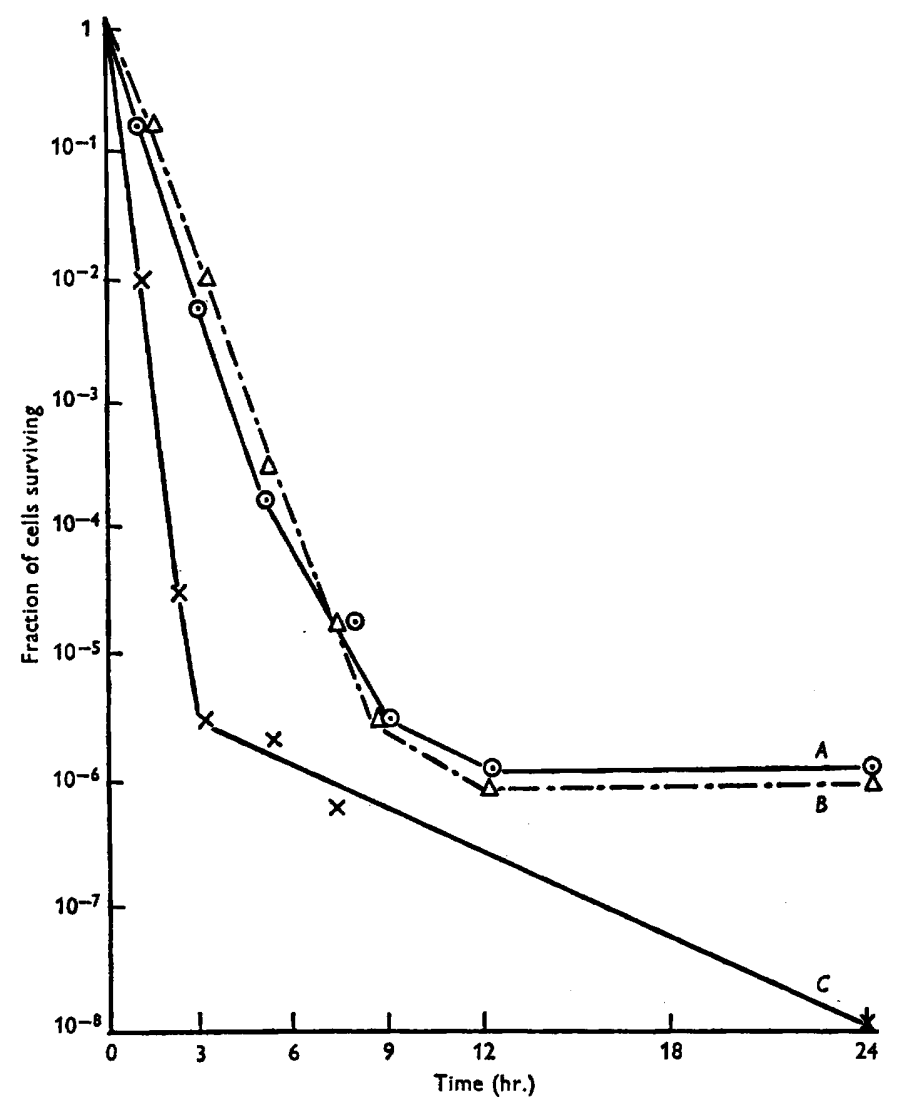

Fig. 3. Staph. aureus, $A$ and $B$ replicate experiments. Initial counts $10^{9.3}$ and $10^{9} / \mathrm{ml}$. respectively; $C$, later experiment with more efficient shaking. Initial count $10^{8.5} / \mathrm{ml}$.

\section{Biological factors determining resistance}

The results described above indicate both that considerable differences may exist between different species of micro-organisms, and also that a few members of an apparently homogeneous culture may differ sharply from the rest in their resistance towards mechanical disintegration. In the experiments to be described we attempted to correlate these findings with differences in the other biological characteristics of the species and individuals concerned.

Resistance of spores to staining. This, like resistance to shaking, might be regarded as a property of the cell-wall. When $B$. subtilis is grown on a rich medium, such as blood-agar, the spores are readily stained by the ZiehlNeelsen technique: on a relatively poor medium, e.g. $0.05 \%$ peptone-agar, the spores are larger and less readily stained. Suspensions prepared from spores grown on these two media did not differ in D.R.T. 
Resistance of vegetative cells to heat. A suspension of Staph. aureus was shaken for $15 \mathrm{hr}$, the viable count becoming constant at 1000-2000/ml. A control was prepared by sterilizing a similar suspension $\left(60 \mathrm{~min}\right.$. at $\left.60^{\circ}\right)$ and adding fresh unshaken organisms to give a count of $1000-2000 / \mathrm{ml}$. Both suspensions were then placed in a bath at $60^{\circ}$ and a loopful from each stroke-inoculated on

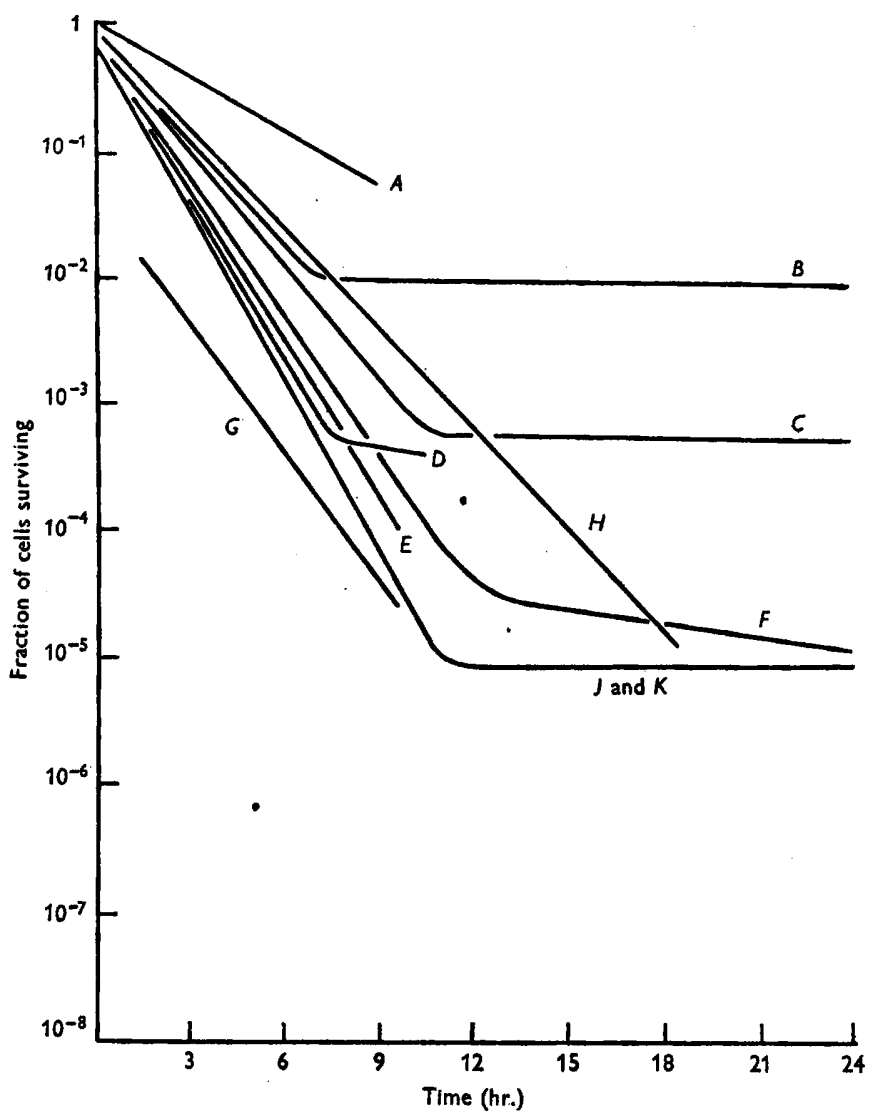

Fig. 4. Susceptibility of different species to destruction by shaking with minute glass beads. $A$, Brewers' yeast, initial count $10^{5} / \mathrm{ml}$; $B, B$. subtilis, initial count $10^{9} / \mathrm{ml}$.; C, B. mesentericus, initial count $10^{8} / \mathrm{ml}$; $D$, Enterococcus, initial count $10^{\circ} / \mathrm{ml}$; $E$, Pneumococcus, initial count $10^{\circ} / \mathrm{ml}$; $F, B$. anthracis, initial count $10^{8.8} / \mathrm{ml}$; $G$, Corynebacterium xerosis, initial count $10^{7.3} / \mathrm{ml}$.; H, Myco. smegmatis, initial count 10 $10^{9.3} / \mathrm{ml}$; J, Shigella sonnei, initial count $10^{8} / \mathrm{ml}$; $K$, Salm. paratyphi $B$, initial count $10^{8.5} / \mathrm{ml}$.

nutrient agar at $5 \mathrm{~min}$. intervals. Both suspensions became sterile after 35-40 min. There was therefore no correlation between heat- and mechanicalresistance in this organism.

Penicillin resistance. Cells of Staph. aureus and Shigella sonnei which were resistant to shaking were normal in their sensitivity to penicillin.

Age of culture. A $4 \mathrm{hr}$. culture of Staph. aureus gave a D.R.T. of $2 \cdot 3 \mathrm{hr}$, compared with $1.4 \mathrm{hr}$. for the usual 16-20 hr. cultures. Young cultures are generally regarded as being more susceptible to injurious influences than 
mature cultures, but young cells are also known to be abnormally large and we found large organisms to be more resistant to our treatment-cf. yeast and the large-capsule strains of Aerobacter spp. described below.

Capsules. Through the courtesy of Dr J. P. Duguid, of this Department, we examined three strains of Aerobacter aerogenes: Aerobacter I, a strain with a capsule of about $1 \mu$ radius; Aerobacter IA, the same organism grown on a medium (agar containing $1 \%$ glycerol and $0.1 \%$ peptone) on which it produced a capsule 5-10 $\mu$ radius; Aerobacter II, with a small capsule, 0.25 $\mu$ radius. The size of the capsules was measured in Indian ink preparations. There appeared to be a marked correlation between capsule size and resistance. The

Table 3. Proportion of smooth colonies among resistant and normal organisms

\begin{tabular}{llc} 
& \multicolumn{1}{c}{ Shigella sonnei } & Salm. paratyphi B \\
Normal & 16 smooth in $405(4 \cdot 0 \%)$ & 8 smooth in $338(2 \cdot 4 \%)$ \\
Resistant & 41 smooth in $272(15 \%)$ & 31 smooth in $300(10 \cdot 3 \%)$
\end{tabular}

D.R.T. was $2.7 \mathrm{hr}$. for Aerobacter II, $4.8 \mathrm{hr}$. for Aerobacter I, while Aerobacter IA was completely resistant. The suspension of the latter was highly viscous $\left(\eta \mathbf{1 1 \cdot 2}\right.$ relative to water at $\left.37^{\circ}\right)$ and it was possible that the viscous material protected the organism. For purposes of comparison a suspension of Staph. aureus was shaken in a viscous medium (hog gastric mucin, $\eta 18.3$ relative to water at $37^{\circ}$ ). The D.R.T. was $2.6 \mathrm{hr}$., compared with $1.4 \mathrm{hr}$. for the control shaken in saline. The viscosity of the solution could thus play a part in protecting the organisms, but it cannot account for the resistance of the highly capsulated Aerobacter spp.

The capsulated pneumococcus gave a D.R.T. $2 \cdot 45 \mathrm{hr}$. compared with 1.4 hr. for the non-capsulated Staph. aureus. The enterococcus, also non-capsulated, gave a D.R.T. of $\mathbf{2 \cdot 2} \mathrm{hr}$. however. This organism is known to be abnormally resistant to other destructive agents, e.g. heat. But even if the protective action of a capsule be established, we have no evidence whether this effect is specific or is due only to the larger size of the organism. Nor have we established whether the resistance of large organisms is real or due to our application to them of a technique developed with normal-sized non-capsulated bacteria (Bact. coli, Staph. aureus). The highly resistant survivors remaining after shaking normally susceptible organisms exhibit no abnormality in either size or capsulation.

Colony form. In Shigella sonnei and in Salm. paratyphi $\boldsymbol{B}$ the resistant organisms gave a higher proportion of smooth colonies than the initial suspensions (Table 3). But though the differences were statistically significant $(t>4$ in both cases), it is difficult to regard the smooth organisms as playing any part in the phenomenon of resistance. A comparison of the relative resistance of suspensions of rough and 'smooth organisms failed to reveal any significant differences.

\section{DISCUSSION}

Our results confirm the conclusion of Curran \& Evans (1942) that agitation with small inert particles may exert a powerful bactericidal action. But sterility is not readily obtained by this method: a small but definite proportion 
of the organisms shows resistance of an order different from that of the remainder of the culture. These 'resistant' cells did not differ from the normal cells in any of the other characteristics which we investigated. Curran \& Evans (1942), whose investigations were confined almost entirely to spores, assessed the efficiency of mechanical destruction by the number of surviving organisms after $5 \mathrm{hr}$. shaking. This, however, is a function of several factors: the initial rate of killing, the proportion of resistant cells, and the rate at which the latter are killed. As the number of survivors after $5 \mathrm{hr}$. is the only figure cited in the majority of their experiments, comparison of their results with ours is not possible in most cases.

Our investigations with different species suggest that capsules may exert a protective influence, but it is not certain whether this is due solely to the increased size of the capsulated organism. Nor do we know whether the conditions of our experiments, developed with non-capsulated bacteria, are the most suitable when dealing with larger organisms. No correlation was found between resistance to mechanical destruction and the other biological characteristics of the organisms investigated. Whilst within one group of three closely related organisms-the Gram-negative bacilli-identical results were obtained, within another group of three biologically related organisms-the aerobic sporing bacilli-there was wide variation in resistance.

We are much indebted to Prof. T. J. Mackie for his interest in this work which was performed during the tenure by one of us (H.K.K.) of the Lewis Cameron Teaching Fellowship of Edinburgh University.

\section{REFERENCES}

Curran, H. R. \& Evans, F. R. (1942). The killing of bacterial spores in fluids by agitation with small inert particles. J. Bact. 43, 125.

Gale, E. F. (1947). Chemical Activities of Bacteria, p. 186. London: University Tutorial Press. 